\title{
Japanese plutonium suspected in French tests
}

Paris \& Tokyo. Plutonium separated from Japanese spent fuel rods sent to France for reprocessing could be ending up in French nuclear weapons. This is one conclusion of a new report that provides evidence that safeguards by international authorities may not always be implemented. If confirmed, the report would embarrass the Japanese government, which opposes the resumption of French nuclear tests.

The report, commissioned by a group of

\section{IMAGE UNAVAILABLE FOR COPYRIGHT REASONS}

\section{Cogema de La Hague; providing for weapons?}

Japanese consumer organizations and pressure groups opposed to nuclear weapons and nuclear power, was produced by the Paris-based World Information Service on Energy (WISE), a consultancy on energy and environmental matters, whose clients have ranged from Greenpeace to the French ministry of environment.

The WISE report argues that because nuclear reprocessing facilities have both civilian and military roles, there can be no guarantee that some plutonium derived from reprocessing of Japanese nuclear fuel has not ended up in French weapons. Japan has agreed contracts worth more than FF20 billion (US\$4 billion) with the French company Cogema for the reprocessing of 2,925 tonnes of spent fuel, which would yield 23 tonnes of plutonium.

Under the terms of international safeguards all of this separated plutonium must be returned to Japan. But the returned plutonium need be only 'equivalent' to that originally sent. Because the isotopic composition of the first large (1.5-tonne) shipment of plutonium returned to Japan in late 1992 does not match the burn-up rate of typical Japanese spent fuel discharged in the 1980s, "it was certainly not of Japanese origin", concludes the report. Cogema's reprocessing plant at La Hague has produced plutonium for the French bomb programme, and has also separated plutonium from Japanese spent fuel. Under Cogema's present system, mixing of military and civilian plutonium could occur.

Moreover, claims the report, there are good reasons to believe that "old" Japanese plutonium derived from fuel reprocessed in the 1970s and 1980s may have been "swapped" for "fresher" material in the 1992 shipment, which is more suitable for MOX (mixed oxide fuel) production.
The conclusion that the plutonium returned to Japan is not of Japanese origin raises two issues. The first is diplomatic, because Japan opposes the planned. French tests in the Pacific. Some Japanese pressure groups last week submitted a petition to the government calling for an end to the reprocessing agreement with France unless firm assurances can be given that Japanese plutonium is being properly safeguarded and not ending up in the French nuclear weapons programme. But the second and perhaps more serious issue concerns the ability of international organizations to verify agreed safeguards concerning the handling of nuclear materials. In principle, spent fuel ن. reprocessed in France is subject to two international safeguard regimes, those of the International Atomic Energy Authority (IAEA) and of Euratom.

But while foreign waste is processed in 103 facilities in France, according to the report, only eight are subject to IAEA control. Moreover, according to an IAEA official cited in the report, the IAEA does not even these inspect all eight facilities because of "budget problems", and instead relies for verification on reports from the French authorities. The international agencies have been "publicly misleading people about their technical capacities", says Mycle Schneider, who is one of the report's authors. Schneider claims that nuclear waste sent to France enters a "plutonium pool", where it becomes impossible to trace the ownership of material, and from which it could be removed without detection.

Japan's Science and Technology Agency, which oversees Japan's plutonium policy sees "no problem" with the reprocessing at

\section{Leaked letter confirms UK budget cuts}

London. The leaking of an official letter written by the director general of research councils, John Cadogan, confirms that the British science budget will be reduced by $£ 21$ million (US\$34 million) in 1996-97 to help pay for the government's technologyrelated research initiatives.

It suggests earmarking one per cent of this year's budget for next year, for project proposals from research councils that relate to technology-related initiatives such as the Realizing Our Potential Awards Scheme (ROPAS).

"Ministers agree that it would be prudent to have available about $£ 21$ million for a further round of the initiatives approved this year as well as for any new initiatives and or realignments which might follow Foresight," Cadogan writes.

John Mulvey from the pressure group Save British Science says the letter's contents are no surprise. "We have long been aware that money for exercises such as
La Hague, according to a spokesman. The agency insists that the safeguards of the IAEA are adequate and are being strictly observed at the French plant. Also, they are backed up by Euratom safeguards, it says.

However, the agency does admit that mixing of plutonium from different sources may occur, but says that it is only a requirement that an equivalent quantity of fissile plutonium be returned to Japan as is separated from Japanese fuel.

The IAEA comments that it has no jurisdiction over France, which is a nuclear weapons state, and that it only carries out inspections at La Hague on a voluntary basis. Euratom, which has responsibility for tracing all nuclear materials in the European Union, has greater powers. Its 250 inspectors trace all materials and carry out on-site inspections. But Euratom has no access to military faciltities, and a spokesperson admits that the dual civil/military nature of many French nuclear plants complicates the inspection procedures. The possibility that foreign nuclear waste might end up in military programmes cannot be discounted, he says, given the practice of "flag-swapping" equivalent nuclear materials. But he emphasizes that the tracking of amounts of equivalent plutonium is well controlled, and complies with international agreements.

Cogema describes the report's conclusions as an "intellectual construction". Admitting that plutonium from different sources is "obviously mixed" during reprocessing, Cogema asserts that all international agreements and contracts have been respected. It further argues that plutonium handled at La Hague is not weapons grade.

Declan Butler \& David Swinbanks

Technology Foresight would have to come from existing budgets that are declining in real terms."

John Battle, spokesman on science for the Labour Party, says the letter was a "betrayal of trust". Labour, says Battle had warned that "the government's commitment to science research has been looking increasingly shaky" following the transfer of the Office of Science and Technology from its Cabinet position into the department of trade and industry.

But Kenneth Pounds, chief executive of the Particle Physics and Astronomy Research Council (PPARC), points out that in May the government pledged $\mathfrak{£ 4 0}$ million "of new money" over three years for projects linked with Technology Foresight. But he added that research councils were feeling "a little nervous" at the prospect of making room in their budgets for schemes such as ROPAS "without damaging existing research commitments".

E. M. 